\title{
BIOMECHANICAL DYSFUNCTION IN PATIENTS WITH PRIMARY OSTEOARTHRITIS OF THE KNEE: THE ROLE OF PHYSICAL THERAPY
}

\section{ZABURZENIA BIOMECHANICZNE U PACJENTÓW Z PIERWOTNĄ CHOROBĄ ZWYRODNIENIOWĄ STAWU KOLANOWEGO: ROLA TERAPII FIZYCZNEJ}

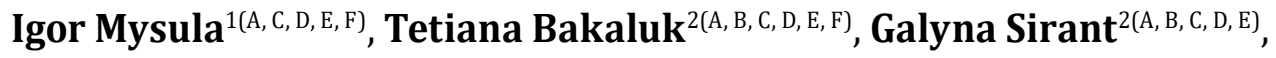 \\ Nataliya Sydliaruk $^{2(A, B, E, F)}$, Yuriy Mysula ${ }^{2(A, D, E, G)}$
}

${ }^{1}$ Pope John Paul II State School of Higher Education in Biała Podlaska, Poland

${ }^{2}$ Ivan Horbachevsky Ternopil State Medical University, Ukraine

Authors' contribution Wkład autorów:

A. Study design/planning zaplanowanie badań

B. Data collection/entry zebranie danych

C. Data analysis/statistics dane - analiza i statystyki D. Data interpretation interpretacja danych E. Preparation of manuscript przygotowanie artykułu F. Literature analysis/search wyszukiwanie i analiza literatury G. Funds collection zebranie funduszy

Tables: 0

Figures: 0

References: 16

Submitted: 2018 March 28

Accepted: 2018 Jun 26

\section{Summary}

Biomechanical factors such as reduced muscle strength and narrowing of the knee joint play an important role in the initiation and progression of primary osteoarthritis. Pharmacological treatment is not always effective and, in some cases, is accompanied by side effects. However, some factors associated with osteoarthritis, such as muscle dysfunction and decreased physical activity, may be improved through physical rehabilitation. In this article, we describe the pathogenesis, clinical manifestations and approaches to physical rehabilitation for biomechanical disorders associated with primary osteoarthritis of the knee (gonarthrosis).

Keywords: primary osteoarthritis of knee, biomechanical dysfunction, physical rehabilitation

\section{Streszczenie}

Czynniki biomechaniczne, takie jak zmniejszona siła mięśni i zwężenie szczeliny stawowej, odgrywaja ważną rolę w inicjacji i progresji pierwotnej gonartrozy. Zabiegi klasyczne, głównie farmakologiczne, nie zawsze są skuteczne, a w niektórych przypadkach towarzyszą im niepożądane działania uboczne. Jednak czynniki związane z chorobą, takie jak zaburzenia funkcji mięśni i zmniejszona aktywność fizyczna, można wyeliminować dzięki metodom rehabilitacji fizycznej. W niniejszym artykule została opisana współczesna koncepcja dotycząca patogenezy, objawów klinicznych i metod rehabilitacji fizycznej zaburzeń biomechanicznych u pacjentów z pierwotną gonartrozą.

Słowa kluczowe: choroba zwyrodnieniowa stawu kolanowego, zaburzenia biomechaniczne, rehabilitacja fizyczna

\section{Introduction}

In recent years, osteoarthritis $(\mathrm{OA})$ has attained increasing medical and social significance due to its substantial prevalence, the rapid development of functional disorder (especially with joints of the lower extremities), the presence of both temporary and permanent disability, and a decline in the patients' quality of life. OA is present in $10-15 \%$ of the population in Europe and the United States. It affects people of all age groups, but is most common in the elderly. After 60 years of age, the prevalence of OA is twice that observed in middle-aged people. While the exact cause of OA remains unknown, the pathogenetic role of biomechanical dysfunction is proven. For knee joints, mechanical demand and biomechanical changes are important factors for the initiation and progression of OA [1].

\section{Aim of the work}

This review focuses on the effects of biomechanical dysfunction on the pathogenesis and progression of primary $\mathrm{OA}$ of the knee and the role of physical therapy in its management. 


\section{Brief description of current knowledge}

The decline in the functional volume of the articular cartilage in patients with OA of the knee is uneven, is accompanied by pathological changes in the axis of the lower limb and is a result of dysfunction of connective tissue and muscular structures [2].

In clinical practice, chronic pain is common in patients with OA due to local non-articular pathogenetic mechanisms. External articular changes in patients with OA of the knees result in compensatory, adaptive reactions. In such cases, the trigger mechanisms of pain are anatomical, functional and biomechanical. Muscles surrounding the knee are sensitive to both internal or external negative influences on the joint. [3]. Therefore, $\mathrm{OA}$ is often accompanied by muscular dysfunction which leads to limitation of joint mobility and pain.

Muscles play a crucial role in maintaining joint mobility, stability and function [4], helping to absorb mechanical stresses and transfer forces through the joints and provide dynamic resistance to normal and damaged joints [4]. It is known that nociceptive impulses in and around affected joints inhibit the activity of muscles and spinal nerves. Such protective inhibition affects not only the condition of muscles which directly support the joint, but can also affect the activity of other distant muscles. According to the multiple researchers [4], disorders of proprioceptive impulses lead to a decrease of periarticular muscle tone and, as a consequence, an increased mechanical load on the joint.

The stability of the knee is provided by active (dynamic) stabilizers that include muscle-tendon complexes and passive (static) stabilizers that include the joint capsule, articular cartilage, ligaments, meniscus, and bone. The dynamic stabilizers provide the most opportunity for compensatory stability [5]. The most important muscle stabilizer is the quadriceps, without which stability of the knee is not possible. Its strength and precise coordination can even compensate for the failure of ligament function. Weakness of the quadriceps may be a risk factor or even an etiological factor for pathological changes in patients with OA of the knees. Quadriceps weakness was found in patients with preclinical and clinical gonarthrosis.

According to the previous studies $[3,4,6]$, muscle weakness was associated with the initiation and progression of $\mathrm{OA}$ of the knee and is one of the earliest and most frequent symptoms in patients with OA of knee. It is a more likely predictor of disability than joint narrowing or the presence of pain. Research [3] has also shown that an important risk factor for the development of $\mathrm{OA}$ of the knees is specific weakness of the quadriceps, which develops as a result of joint instability and decreased muscle capacity during and after physical exercise. In addition, there is a decrease in strength and endurance of many groups of muscles with age and the development of $\mathrm{OA}$, especially of the knees, can exacerbate this weakness and lead to functional disorders. Reduced physical activity resulting from pain in patients with OA leads to further decreases in muscle volume and increased joint instability [4]. Consequently, chronic articular pain in patients with OA leads to muscle atrophy, weakness, an imbalance between agonist and antagonist muscles, restriction of joint movements and aggravation of periarticular tissues.

Physical therapy is recommended in clinical guidelines for the treatment of $\mathrm{OA}$ of the knee published over the last decade (NICE (2008), EULAR (2007, 2013, 2016), OARSI (2010), ACR (2012), ESCEO (2014, 2016)).

Different physical exercises are used in rehabilitation programs. These include aerobic exercises to increase endurance and strengthening exercises of different intensity, from moderate to high, to support the muscles around the joints, especially in the case of instability.

Physical training in patients with OA should be directed towards joint stabilization and relieving joint tension by strengthening muscles and ligaments [7]. Static tension on skeletal muscles leads to improved muscular strength and increased mass of hypotrophic muscles, with minimal stress on the affected joint.

The objective of physical rehabilitation in the presence of chronic inflammation with pronounced synovitis is the reduction of intra-articulation pressure. This can be achieved by positioning, muscle relaxation exercises (autogenous training, including progressive relaxation) and traction therapy [8]. In the initial stages of synovitis, the main aim of physical rehabilitation is to strengthen the periarticular muscles, since a strong muscle mass provides a dampening function, ensuring a smooth transfer of translational forces to the articular surface, protecting the joint from twisting and hypermobility. Physical activity improves microcirculation in the articular structures, and dynamic exercises improve the circulation of synovial fluid in the joint [9].

Aerobic exercises from mild to moderate intensity are well tolerated by patients with knee $\mathrm{OA}$, and muscle strength training at moderate intensity is well tolerated in elderly patients with OA. Although there is no clear evidence to support which type of exercise (isometric, isotonic, isoquintic, concentric, eccentric or dynamic) maximizes muscle strength [10], exercises with both isometric and isotonic character can be used in rehabilitation programs. 
According to previous studies [11], proprioceptive exercises are better at reducing pain compared with isokinetic exercises and may be more effective in rehabilitation programs for patients with knee OA compared to isometric quadriceps exercises.

Exercises in water have short-term, clinically significant effect on pain and quality of life.

Clinical studies [12] show that modifications to patterns of walking favourably alter knee loads and these biomechanical changes can lead to clinically significant improvement in symptoms. However, further studies are needed to determine the type of modification needed to maximize beneficial effects. Long term benefit requires willingness to learn and commitment from patients.

The maximum beneficial effect of physical exercises on the strength of the knee extensor and flexor muscles was achieved within 6 months after beginning the exercises, was maintained for 1-3 years but usually lost after 5 years. This may due to inadequate intensity or frequency of exercises to maintain benefit [10]. Other studies [13] have shown that benefit of physical therapy is not just on the knee joint muscles but also on the hip muscles, which play a role in the treatment $\mathrm{OA}$ of the knee joint.

The inclusion of treadmill walking in the rehabilitation program for 12 weeks contributes significantly to improving joint function, the ability to perform essential daily tasks and quality of life [14]. Tele-rehabilitation can also be used to improve access to specialty care for the growing number of patients with traumatic injuries [15].

The clinical experience of Solodilov demonstrated that, in elderly patients with OA of the knee, physical exercise, in combination with manual joint mobilization, not only reduces knee symptoms but also has a beneficial effect on joint biomechanics, reducing asymmetry of the knee. As a result of this correction, there is improvement in walking patterns and mobility [16].

However, despite recent studies that show the benefits of exercises for people with OA, the majority of people, especially with lower limb OA, are insufficiently physically active. Patients with OA have different levels of motivation to change their physical activity and a change in behaviour may take many months to become routine. Tele-rehabilitation, motivational interviewing and evidence-based rehabilitation methods are used by health care professionals to help patients with OA achieve mutually agreed physical activity goals.

\section{Conclusions}

1. Pain, muscle weakness and biomechanical dysfunction affect the progression of $O A$, making muscle strengthen exercises of paramount importance in the prevention and rehabilitation of primary OA of the knee.

2. Physical rehabilitation strategies that actively change lower limb biomechanics are a promising strategy for the treatment of symptoms as well as for prevention of OA progression.

3. Different types and combinations of physical rehabilitation, depending on the biomechanical dysfunction, have the potential to improve the adaptive and compensatory function of joints, muscles and other periarticular tissues with minimal risk of adverse events.

\section{References:}

1. Egloff C, Hügle T, Valderrabano V. Biomechanics and pathomechanisms of osteoarthritis. Swiss Med Wkly. 2012; 19: 142. https://doi.org/10.4414/smw.2012.13583

2. Sheveleva N, Minbayeva L, Belyayeva Y. Dinamics of knee joint space asymmetry on x-ray as a marker of knee osteoarthritis rehabilitation efficacy. Georgian Med News. 2017; 264: 16-20.

3. Oiestad BE, Juhl CB, Eitzen I, Thorlund JB. Knee extensor muscle weakness is a risk factor for development of knee osteoarthritis. A systematic review and meta-analysis. Osteoarthritis Cartilage. 2014; 1: 1305-1308. https://doi.org/10.1016/j.joca.2014.02.621

4. Bennell KL, Hunt MA, Wrigley TV, Lim BW, Hinman RS. Role of muscle in the genesis and management of knee osteoarthritis. Rheum Dis Clin North Am. 2008; 34(3): 731-754. https://doi.org/10.1016/j.rdc.2008.05.005

5. Stemberger R, Kerschan-Schindl K. Osteoarthritis: physical medicine and rehabilitation - nonpharmacological management. Wien Med Wochenschr. 2013; 163(9-10): 228-235. https://doi.org/10.1007/s10354-013-0181-9

6. Elboim-Gabyzon M, Rozen N, Laufer Y. Quadriceps femoris muscle fatigue in patients with knee osteoarthritis. Clin Interv Aging. 2013; 8: 1071-1077. https://doi.org/10.2147/CIA.S42094

7. Fransen M, McConnell S, Harmer AR, Van der Esch M, Simic M, Bennell KL. Exercise for osteoarthritis of the knee. Cochrane Database Syst Rev. 2015; 1: CD004376. https://doi.org/10.1002/14651858.CD004376.pub3 
8. Alpayci M, Ozkan Y, Yazmalar L, Hiz O, Ediz L. A randomized controlled trial on the efficacy of intermittent and continuous traction for patients with knee osteoarthritis. Clin Rehabil. 2012; 27(4): 347-354. https://doi.org/10.1177/0269215512459062

9. Khalaj N, Abu Osman NA, Mokhtar AH, Mehdikhani M, Wan Abas WA. Effect of exercise and gait retraining on knee adduction moment in people with knee osteoarthritis. Proc Inst Mech Eng H. 2014; 228(2): 190-199. https://doi.org/10.1177/0954411914521155

10. Jun I. Effectiveness of exercise for osteoarthritis of the knee: a review of the literature. World J Orthop. 2011; 2(5): 37-42. https://doi.org/10.5312/wjo.v2.i5.37

11. Adesola 00, Matthew OBO, Mariam AH. Comparative effects of proprioceptive and isometric exercises on pain intensity and difficulty in patients with knee osteoarthritis: a randomised control study. Technol Health Care. 2016; 24(6): 853-863. https://doi.org/10.3233/THC-161234

12. Simic M, Hinman RS, Wrigley TV, Bennell KL, Hunt MA. Gait modification strategies for altering medial knee joint load: a systematic review. Arthritis Care Res (Hoboken). 2010; 63(3): 405-426. https://doi.org/10.1002/acr.20380

13. Thorp LE, Wimmer MA, Foucher KC, Sumner DR, Shakoor N, Block JA. The biomechanical effects of focused muscle training on medial knee loads in OA of the knee: a pilot, proof of concept study. J Musculoskelet Neuronal Interact. 2010; 10:166-173.

14. Peeler J, Ripat J. The effect of low-load exercise on joint pain, function, and activities of daily living in patients with knee osteoarthritis. The Knee. 2018; 25(1): 135-145. https://doi.org/10.1016/j.knee.2017.12.003

15. Tsvyakh A, Hospodarskyy A. Telerehabilitation of patients with injuries of the lower extremities. Telemed J E Health. 2017; 23: 1011-1015. https://doi.org/10.1089/tmj.2016.0267

16. Solodylov RO. [Physiologically-biomechanical analysis and study of the functional state of knee joint in elderly women with gonarthrosis]. Zhurnal medyko-byolohycheskykh yssledovanyi. 2017; 5(2): 74-81 (in Russian). 